\title{
The candidate
}

\author{
Washington 2.0
}

\section{Jack McDevitt}

The high and low points of my career came on the same night: when we beat George Washington, and Peter Pollock returned to the White House for a second term.

Well, okay. It wasn't really Washington; it was an artificial intelligence programmed to behave like Washington. But a lot of people got confused. When you've been in politics as long as I have, you know how easily people get confused.

Fortunately.

President Pollock's numbers were down, but the Democratic candidate put everybody to sleep. So we knew it would be close. Then Washington showed up. He was a software package developed at the University of Georgia to play the part of the first president in seminars. He was so believable that somebody at the school put him on a local radio show, and next thing he was a national phenomenon: people were desperate for a candidate they could believe in. The general gave an interview to the Florida Times-Union, the wire services picked it up, and, by God, he did sound like George Washington.

I was running the Pollock campaign, and we all had a good laugh when they tried to put Washington on the ballot in Georgia. The Democrats tried to block it. Candidates have to be born, they said, and have to be at least 35 years old.

We could have stopped it then. But if Washington got into the general election, he'd pull votes from the Democrats: we knew our base wasn't going to support a candidate who wasn't even human. So I called in some favours and the Supreme Court ruled they could find no reason to suppose he was not a 'Washington-equivalent. He was therefore clearly well past the minimum age limit. As to the requirement he be born, the software had been written in Georgia, and the meaning of 'born', said the court, is not limited to biological events.

I watched Washington on cable, and he was persuasive. He didn't like frivolous spending; didn't like unaffordable medications, didn't like corruption. I thought he came across as wooden, and maybe a trifle stern. Americans, I thought, don't like being lectured.

They could simply have done the whole thing electronically, but somebody in his campaign was smarter: he was housed in a
Coreolis 5000, and they dutifully set it on a table along with a screen which provided an animated image from the Gilbert Stuart portrait, except they'd cut the General's hair and put him in a business suit.

By midsummer he was making the rounds of the network talk shows. The week before he made his first appearance on Meet the Press, he passed the Democratic candidate and moved into the runnerup spot. The liberal media decided the Democratic candidate was a lost cause.

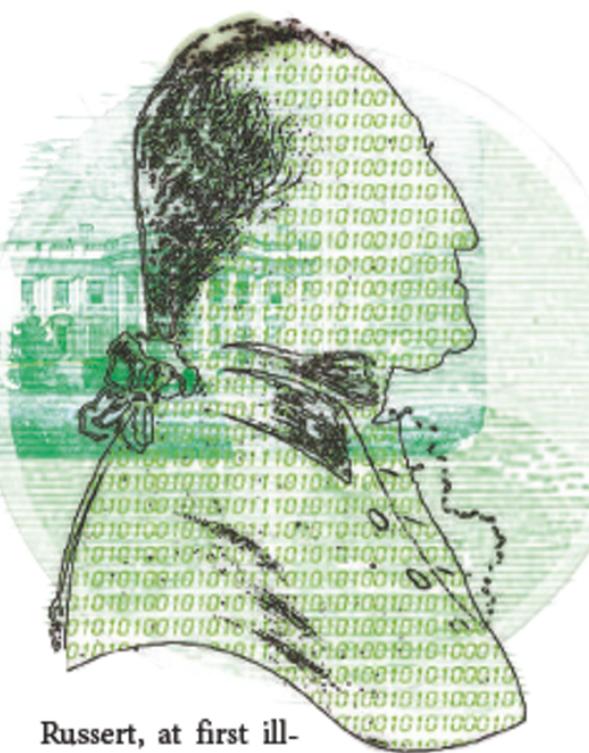

at-ease talking to the machine, warmed to him. "Are you really George Washington?" he asked.

"The man's dead," said Washington. "But I'm everything he was."

Russert asked about the Intervention, which had become another of those endless wars. "We intended the nation to lead by example," the General said. "We would not willingly have plunged into the affairs of others. Keep your own house in order. Do it competently, and the world will follow."

We realized, belatedly, that we were in a race. After his appearance with Jon Stewart, there was no longer any doubt. ${ }^{\alpha} \mathrm{I}$ would prefer," he told the vast audience, "that you not vote for me. And I'll tell you why: people should be governed by other people, not by software. If the voters insist, I will do my best. But I fear the long-term potential.

So we went after him: doesn't want the job. And we looked at his record: do we really want a former slave-owner in the White House?

We knew we couldn't touch him on national security, but we demanded to know where he stood on the issues. "What about Roe vs Wade?"

${ }^{\text { }}$ Put it aside for now, he said. "At the moment, we have bigger problems." We got some of our base back on that one.

"Gay marriage?"

"I cannot see that anyone is harmed. We should be careful about codifying moral strictures. They change too easily."

We got some more of our people back. We talked about Frankenstein. This appealed to voters so we kept hitting it. $\zeta$ Vote for People, we said. We found a few physicists who were willing to say publicly that an artificial intelligence could develop a glitch: would you trust the Black Box in the hands of a computer?

We held on. We were still holding at 2:00 a.m. election night, when we went down to the last district in Indiana, but we took the state by a few hundred votes and that put us over the top.

Pollock went on TV after Washington conceded. He said how we'd saved the nation from a hardware conspiracy. (He tends to say things like that when he gets off script.) When it was over, he took me aside to express his appreciation. A Rainbow 360 rested on the coffee table. "We saved the country, Will," he said. "We'll get legislation to bar the things from holding office. Otherwise, I guess, they'll trot out Abe Lincoln next time."

"Yes, ${ }^{,}$I said. "And congratulations, Mr President." It meant four more years for me too, as chief political adviser.

"No. It's not on the cards, Will." He looked almost genuinely pained. "We have to look to the future."

That was a shock. "What do you mean, sir?"

"It was a near thing, this election. We miscalculated our opponent's strength. I mean, incumbent president and all. It should have been easy."

"But-?"

"I need someone who won't be taken by surprise."

I was trying not to let my anger show. "Who did you have in mind, sir?"

He smiled at the Rainbow 360. "Will meet Karl Rove."

Jack MCDevitt is the author of 12 sciencefiction novels and more than 60 stories. His Omega won the John W. Campbell Memorial Award for best novel in 2004 . He has won numerous other awards and has been a consistent Nebula finalist. His current novel is Seeker. He lives in Georgia, USA. 